\title{
Towards magnetometric characterization of soil pollution with rare-earth elements in industrial areas of Upper Silesian Industrial Area, Southern Poland
}

\author{
Piotr Fabijańczyk ${ }^{1}$ - Jarosław Zawadzki ${ }^{1}$. Tadeusz Magiera ${ }^{2}$
}

Received: 20 October 2018 / Accepted: 31 May 2019 / Published online: 7 June 2019

(C) The Author(s) 2019

\begin{abstract}
The paper presents systematic study concentrations of selected rare-earth elements, namely La and Ce in soils of highly industrialized regions using geochemical and magnetometric measurements as well as geostatistical methods. Soil magnetometry was used to determine if the concentrations of $\mathrm{La}$ and $\mathrm{Ce}$ in soil could be a result of anthropogenic pollution or natural soil properties. Results of analyses revealed that the highest concentrations of $\mathrm{La}$ and Ce were observed near a waste heap of the plant producing and processing batteries, and in the region of the Jizera Mountains, natural REE-rich minerals are very common. It was also found that the lowest concentrations of $\mathrm{La}$ and $\mathrm{Ce}$ in soil were observed in forested areas of where the dominant type of pollution sources was associated with the metallurgical industry. Distributions of magnetic susceptibility in soil profiles collected in areas with predominant industrial influence showed visible peak in topsoil, what confirmed anthropogenic origin of $\mathrm{La}$ and $\mathrm{Ce}$ in soil. In areas where large volumes of wastes were deposited in past, industrial activity, vertical distributions of soil magnetic susceptibility showed also secondary, strong peak in subsoil. Thus, the results reveal that magnetometric measurements in soil profile might be useful as supplementary method for analyzing of concentrations of rare-earth elements. Contrary, magnetometric measurements performed on the soil surface were poorly correlated with a concentration of $\mathrm{La}$ and $\mathrm{Ce}$ in soil, because they have weaker magnetic properties than typical fly ashes emitted by industry.
\end{abstract}

Keywords Soil pollution $\cdot$ Rare-earth elements $\cdot$ Magnetometry $\cdot$ Magnetic susceptibility $\cdot$ Industrial areas $\cdot$ Geostatistics

\section{Introduction}

The rare-earth elements (REE) include the lanthanide elements and additionally Sc and Y. The REE can be divided into two groups: the light REE such as $\mathrm{La}, \mathrm{Ce}, \mathrm{Pr}, \mathrm{Nd}, \mathrm{Sm}$, $\mathrm{Eu}$, and the heavy REE such as Gd, Tb, Dy, Ho, Er, Tm, Yb, $\mathrm{Lu}, \mathrm{Cs}$, and $\mathrm{Y}$. The characteristic of REE is that they have

Jarosław Zawadzki

j.j.zawadzki@gmail.com

Piotr Fabijańczyk

piotr.fabijanczyk@pw.edu.pl

Tadeusz Magiera

tmagiera@ipis.zabrze.pl

1 Warsaw University of Technology, Faculty of Building Services, Hydro and Environmental Engineering, Nowowiejska 20, 00-661 Warsaw, Poland

2 Institute of Environmental Engineering Polish Academy of Sciences, M. Skłodowskiej-Curie 34, 41-819 Zabrze, Poland similar physical and chemical properties, and often occur in the same ores (Hu et al. 2006).

The magnetic properties of REE and their compounds are very important for industry. The REE and their compounds are used for production of permanent magnets that are part of disk drives, many electronic parts, lasers, thermal jet coatings, or new generation batteries (Jarosinski 2016). REE have been identified by (Seredin and Dai 2012) as critical resources, characterized by limited amounts of ores, considerable dispersion of their minerals, and lack of possibility of their substitution. $\mathrm{Nd}, \mathrm{Eu}, \mathrm{Tb}, \mathrm{Y}$, and Er were classified as critical REE that are in high demand. The rest of REE were not found as hard-to-reach ( $\mathrm{La}, \mathrm{Pr}, \mathrm{Sm}$, and $\mathrm{Gd})$ or as available in sufficient quantities ( $\mathrm{Ce}, \mathrm{Ho}, \mathrm{Tm}, \mathrm{Yb}$, and $\mathrm{Lu}$ ). Usually, REE are obtained from bastnaesite (USA, China), monazite (China, USA, Australia, Brazil, India Malaysia, Sri Lanka, and Thailand), and laterite. The major producers of REE are China, USA, and India. As it was analyzed (Kowalczyk 1989), ores containing REE can be also found in Poland, however, in limited quantities. Monazite, xenotile, 
apatite, and zirconium were found mostly in Lower Silesia region, especially near Szklarska Poręba town, and near Białystok town, in a form of carbonatite.

As it was analyzed, significant amounts of REE can be found in secondary and waste sources, such as phosphogypsum, electrical and electronic wastes, or used catalytic converters (Jarosinski 2016). Of this group, the most important source is electronic wastes that are produced in significant amounts every year. Particularly rich in REE are used permanent magnets, $\mathrm{Fe}_{14} \mathrm{Nd}_{2} \mathrm{~B}$ or $\mathrm{Sm}_{2} \mathrm{Co}_{5}$. The $\mathrm{Nd}$ content in these magnets is about $24 \%$, and Dy levels are up to about $5 \%$.

It was also studied by Jarosinski (2016) that high concentration of rare-earth elements can be found in fly ash produced during the combustion of hard coal. As it was analyzed (Cao et al. 2001), after the dusts containing REE are deposited on the soil surface, they are accumulated in organic and humic soil layers, similarly like other pollutants. The rate of adsorption of REE in soil depends on $\mathrm{pH}$ and soil cation exchange capacity. The availability of REE usually increases with a decrease of $\mathrm{pH}$ and redox potential. Concentrations of REE in soil were also found to be dependent on a presence of organic material and chemical and physical properties of soil (Ran and Liu 1993; Beckwith and Bulter 1993).

In this study, two light REE were selected, namely Lanthanum (La) and Cerium (Ce). As it was previously investigated, the average concentrations of $\mathrm{La}$ and $\mathrm{Ce}$ in soils in Poland were equal to $13 \mathrm{mg} \mathrm{kg}^{-1}$ and $27 \mathrm{mg} \mathrm{kg}^{-1}$, respectively. The typical range of concentrations of $\mathrm{La}$ and $\mathrm{Ce}$ was found to be between 2.7 and $35 \mathrm{mg} \mathrm{kg}^{-1}$ and, 5.5-72 $\mathrm{mg} \mathrm{kg}^{-1}$, respectively (Ramos et al. 2016; Salminen et al. 2005). In this study, the above-described concentrations were treated as reference values for the natural concentrations of $\mathrm{La}$ and $\mathrm{Ce}$ in soil. It is also important to notice that numerous elements, such as $\mathrm{As}, \mathrm{Cd}, \mathrm{Pb}$, and REE do not reveal ferromagnetic properties at room temperature (except $\mathrm{Ga}$, with Curie Temperature, $T_{\mathrm{c}}=290$ ). However, these elements are often emitted by industry mainly as technogenic particles (Magiera et al. 2011). Technogenic particles are compounds containing admixtures of ferromagnetic elements as $\mathrm{Fe}, \mathrm{Co}$, or $\mathrm{Ni}$, and reveal strong magnetic properties that can be measured and analyzed using soil magnetometry.

As it was presented in numerous studies (Petrovský et al. 2000; Spiteri et al. 2005; Magiera and Zawadzki 2007; Fürst et al. 2009; Karimi et al. 2011; Dankoub et al. 2011; Naimi and Ayoubi 2013; Ayoubi et al. 2014; Cao et al. 2015; Łukasik et al. 2015; Fabijańczyk et al. 2017), soil magnetometry is a sophisticated geophysical technique of detecting and determining the level of potential soil pollution with anthropogenic dusts that are emitted by various types of industries (Ayoubi et al. 2014, 2018a, b). Most of magnetometric studies were focused on the determination of soil pollution with heavy metals or Potentially Toxic Elements. According to our knowledge, up to now, they were no soil pollution studies with REE using the field magnetometry methods.

The aim of the study was to investigate the $\mathrm{La}$ and $\mathrm{Ce}$ concentrations in soils located in heavily industrialized areas. Seven measurement areas were selected for field measurements, which were located in different parts of Upper Silesian Industrial Area (USIR) and Jizera Mountains, in southern Poland. The analysis of concentrations of $\mathrm{La}$ and $\mathrm{Ce}$ in soil was based on the chemical measurements and soil samples that were collected in study areas. To determine if the concentrations of $\mathrm{La}$ and $\mathrm{Ce}$ in soil could be a result of anthropogenic pollution or natural soil properties, additional, geophysical measurements were carried out. Simple and rapid magnetometric measurements were used, and soil magnetic susceptibility was measured on the soil surface and in soil profiles.

\section{Materials and methods}

\section{Study area}

Study areas were selected deliberately to ensure variety of types of anthropogenic pressure and ways of land development. They included several types of land use, namely: arable fields, and forested areas, such as natural forests, mountain forests, and urban parks. All study areas selected for this work are characterized in Table 1. Five of them, denoted by A, B1, B2, B3, and C (Fig. 1), were located in the USIR, in southern Poland. In this region, many coal mines, power stations, and steelworks are located, making the USIR one of the most industrialized and polluted parts of Europe. Two areas, denoted by D1 and D2 (Fig. 1), were located in the Jizera Mountains, in a region that is commonly called "the Black Triangle" because of high pollution with industrial dusts emitted by numerous pollution sources in Poland, Germany, and Czechia (Strzyszcz and Magiera 1998).

The study area A (arable field) was located on an arable field about $700 \mathrm{~m}$ away from a heap of metallurgical wastes (Fig. 1) produced during processing of $\mathrm{Pb}-\mathrm{Zn}$ ores, and production of cells and batteries. As it was previously studied (Magiera 2015) in this waste heap, high concentrations of sulfides of $\mathrm{Hg}, \mathrm{Be}, \mathrm{Cu}, \mathrm{Ag}, \mathrm{Se}$, as well as many REE were found. Consequently, the soils in the area A were subjected to pollution by dust generated by the sulphidation processes of the sulfides contained in the waste heap. Subsequently, these dusts were transported by winds to neighboring areas, including the field being investigated. In the area A, agricultural soils were predominant that were systematically cultivated to the depth of about $0.5 \mathrm{~m}$ and had no characteristic 
Table 1 List of study areas, their denotation, type, and number of sample points

\begin{tabular}{|c|c|c|c|c|c|}
\hline \multirow[t]{2}{*}{ Id } & \multirow[t]{2}{*}{ Area } & \multirow[t]{2}{*}{ Type of area } & & \multicolumn{2}{|c|}{ Number of samples } \\
\hline & & & & Soil cores & $\begin{array}{l}\text { On the } \\
\text { soil sur- } \\
\text { face }\end{array}$ \\
\hline \multicolumn{6}{|c|}{ Upper Silesian Industrial Region } \\
\hline A & $0.3 \mathrm{~km}^{2}$ & Arable field & $\begin{array}{l}\text { Limestones, dolomites, marls, oolitic limestones, claystones, } \\
\text { locally mudstones, anhydrites, and gypsum; central trias }\end{array}$ & 20 & 60 \\
\hline B1 & $0.1 \mathrm{~km}^{2}$ & Arable field & Sands and gravels; central polish glaciation & 20 & 36 \\
\hline B2 & $0.1 \mathrm{~km}^{2}$ & Natural forest & & 21 & 36 \\
\hline B3 & $0.1 \mathrm{~km}^{2}$ & Urban park & & 20 & 36 \\
\hline C & $5.5 \mathrm{~km}^{2}$ & Large urban park & & 48 & 72 \\
\hline \multicolumn{6}{|c|}{ Jizera mountains } \\
\hline D1 & $0.2 \mathrm{~km}^{2}$ & Glade in mountain forest & Monzogranites, granodites, and granites; carbon & 33 & 87 \\
\hline D2 & $0.08 \mathrm{~km}^{2}$ & Mountain forest & & 10 & 36 \\
\hline
\end{tabular}

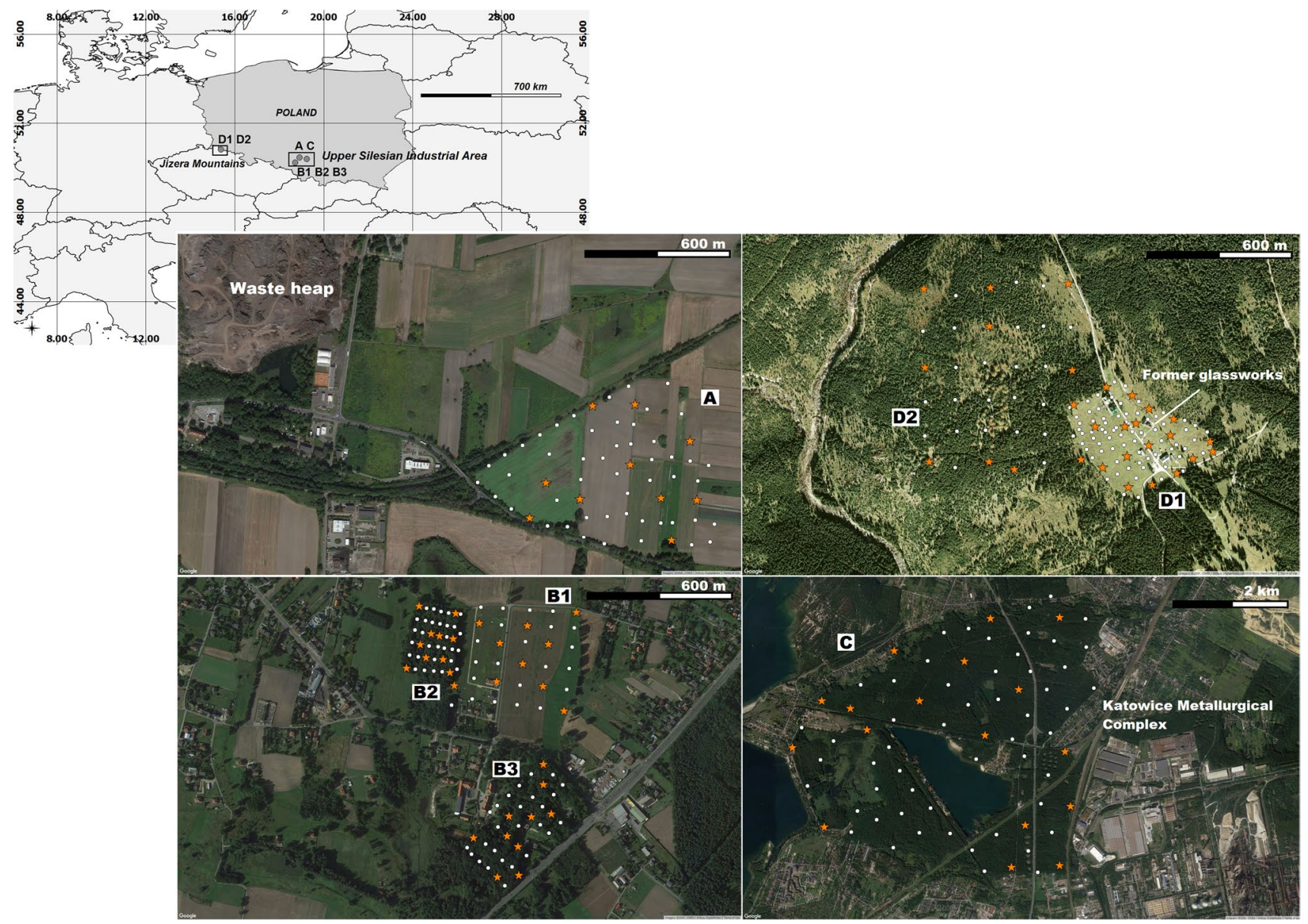

Fig. 1 Location of study areas B1, B2, in Jizera Mountains, and A, C1, C2, C3, and D in Upper Silesian Industrial Region (USIR) and distribution of sample points where geophysical measurements

soil horizons. In the area A, 20 soil cores were collected, and 60 measurements on a soil surface were performed. (denoted by a dot) were made, and soil cores were collected (denoted by star); the coordinate system is WGS84

The area B1 was located on an arable field (Fig. 1) that was recently ploughed to the depth of about $30 \mathrm{~cm}$. The 
study area B2 was located in a natural forest that was surrounded by arable fields. The dominant tree species were old black alder and young maple, oak, and ash. The third measurement site, B3, was located in a park, where the oldest trees were about 150 years old. Some parts of the park were overgrown only with weeds and shrubs. In each of areas B1, B2, and B3, 21 soil cores were collected, and 36 measurements on a soil surface were performed.

The study area $\mathrm{C}$ was the largest out of all study areas. It was located in the direct vicinity of the large steel plant called Katowice Metallurgical Complex (Fig. 1), mainly on a former sand pits that were subsequently reforested. This forest was growing partly on natural podzols but also on initial soils developed in reclaimed areas after former sand exploitation. The predominant tree species were pine trees with some admixtures of deciduous species. The deciduous trees grown mostly in the lower lying and marshy places where sand exploitation reached the impermeable clayey bedrock. Among the deciduous species, birch and poplar were predominant. In the area C, 48 soil cores were collected, and 72 measurements on a soil surface were performed.

The area D1 was situated in the Jizera Mountains in a large forest glade (Fig. 1). In the 19th century, the soils of this area were systematically polluted with significant volumes of wastes from a former glasswork. The adjacent area D2 (Fig. 2) was placed on a hill (about 870 m.a.s.l.) whose western, northwestern, and southwestern parts of a slope were exposed to the long-range pollution from power plants in Poland, Germany, as well as the Czechia (Strzyszcz and Magiera 1998). The soils of areas D1 and D2 were developed from the Jizera granites, and the thickness of soil horizons was very low, and some of them were not fully developed. In the area D1 and D2, 30 and 11 soil cores were collected, as well as 87 and 36 measurements on a soil surface were performed, respectively.

The coordinates of samples collected in the field were recorded using WGS84 coordinate system; however, for spatial analyses, WGS84 coordinates were transformed to the following metric systems: Poland CS2000 zone 5 (EPSG code 2176) and Poland CS2000 zone 6 (EPSG code 2177).

Field measurements were performed in two stages. First, the soil cores were collected (Fig. 1, marked by stars) that were later used in the laboratory for chemical and in-profile magnetometric measurements. Second part of field measurements involved a magnetometric screening of soil surface (Fig. 1, marked by dots). Sample points were distributed possibly evenly in study areas with similar average distance between sample points.

\section{Measurements of soil magnetic susceptibility}

Soil magnetic susceptibility $\kappa$ was measured using the Bartington MS2 Magnetic Susceptibility System, equipped
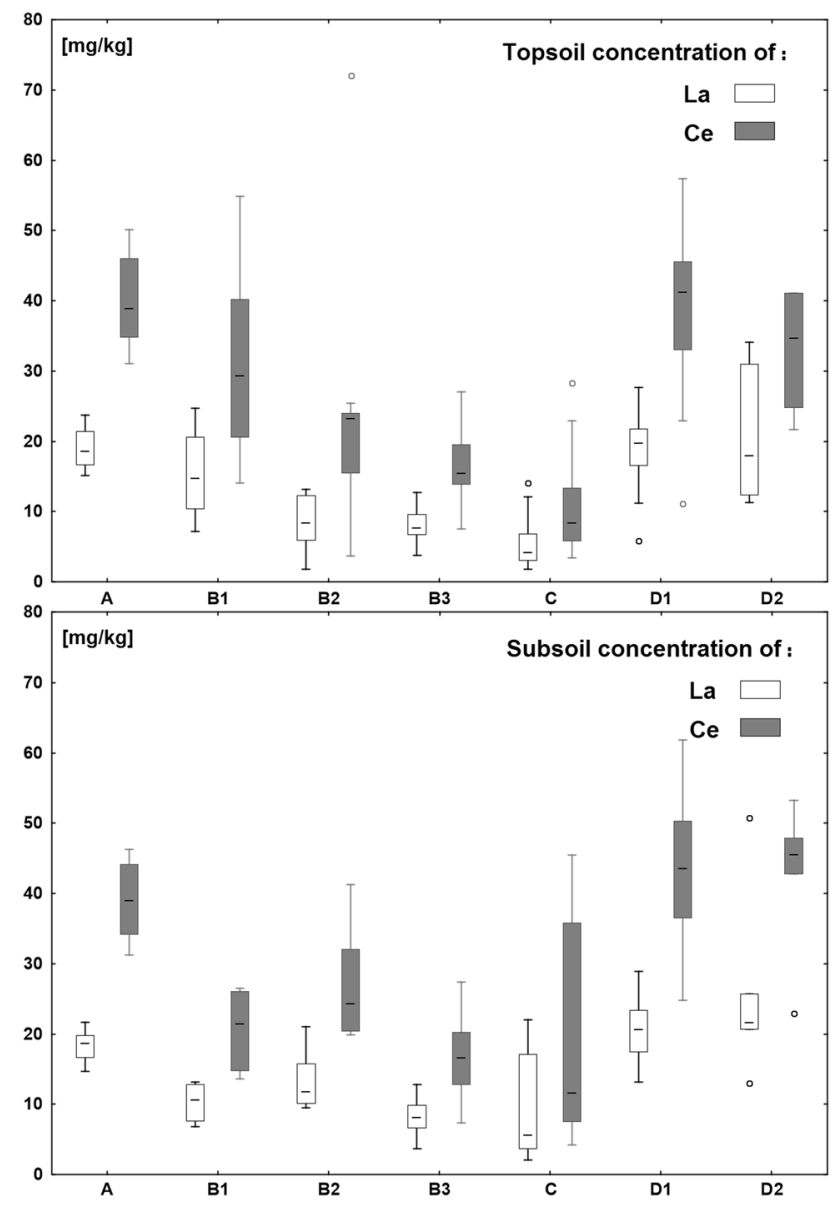

Fig. 2 Box-and-whisker plots of concentrations of $\mathrm{La}$ and $\mathrm{Ce}$ in the topsoil (from a soil surface to a depth of $10 \mathrm{~cm}$ ) and the subsoil (depths below $10 \mathrm{~cm}$ )

with an MS2D loop sensor (Dearing 1994). At a selected location marked by a GPS, $10-15$ measurements of $\kappa$ were made in a circle with a radius of $2 \mathrm{~m}$ to obtain an average and median $\kappa$ value for each sample point.

The MS2D sensor works at a frequency of $0.985 \mathrm{kHz}$ and has a resolution of $2 \times 10^{-6} \mathrm{SI}$. The time needed for a single reading depends on the sensitivity, and is equal to $0.5 \mathrm{~s}$ when the sensitivity is set to $1.0 \times 10^{-6} \mathrm{SI}$ or $1.0 \mathrm{~s}$ when it is set to $0.1 \times 10^{-6} \mathrm{SI}$. The penetration range of the MS2D sensor is equal to $10 \mathrm{~cm}$; however, about $90 \%$ of the total signal is collected at the depth of $6 \mathrm{~cm}$. During our field measurements, the sensitivity of the MS2D sensor was set to $1.0 \times 10^{-6} \mathrm{SI}$.

The distribution of $\kappa$ values along the collected soil cores was measured in the laboratory with an MS2C Bartington sensor (Dearing 1994). The MS2C sensor has a working frequency of $0.565 \mathrm{kHz}$ and the calibration accuracy is equal to $5 \%$. The MS2C instrument can be set to operate in two sensitivity ranges, namely $1.0 \times 10^{-6}$ or $0.1 \times 10^{-6} \mathrm{SI}$. Soil cores that were collected in this study were measured with the sensitivity 
set to $0.1 \times 10^{-6} \mathrm{SI}$. Values of soil magnetic susceptibility were measured with a resolution of $1 \mathrm{~cm}$.

Distributions of $\kappa$ values that were measured in collected soil profiles were used to calculate several, previously studied, parameters (Zawadzki et al. 2009; Blaha et al. 2008). The first calculated parameter was the maximum measured value of $\kappa$ in a soil core. The second parameter was an area under a curve of $\kappa$ values that was calculated for the part of soil profile ranging between soil surface and a depth where $\kappa$ values started to stabilize.

Mass-specific magnetic susceptibility $\chi$ was calculated using collected soil cores. First, soil subsamples were cut from this part of collected soil cores, where maximum value of $\kappa$ was measured. Next, magnetic susceptibility of these subsamples was measured using an MS2B Bartington sensor (Dearing 1994). The MS2B sensor had a resolution equal to $2 \times 10^{-6} \mathrm{SI}$ and its calibration accuracy was equal to $1 \%$. The mass-specific magnetic susceptibility $\chi$ of each soil subsample was determined using the sample container with a nominal volume of $10 \mathrm{~cm}^{3}$. Thus, the calculation of mass-specific susceptibility was done by multiplying the resulting value of volume specific magnetic susceptibility by $10 \mathrm{~cm}^{3}$ and dividing it by the actual mass of the subsample, irrespective of its actual volume enclosed in the sample container.

\section{Measurements of concentrations of La and Ce}

Soil cores were collected using a Humax sampler equipped with plastic tubes with a length of about $30 \mathrm{~cm}$. The concentrations of $\mathrm{La}$ and $\mathrm{Ce}$ were determined using subsamples that were cut from two different parts of each collected soil core: from 0 to $10 \mathrm{~cm}$, and from 10 to $30 \mathrm{~cm}$ beneath the soil surface. These subsamples were air dried, homogenized, and sieved through $2 \mathrm{~mm}$ mesh to separate the soil skeleton or artifacts. After that, about $250 \mathrm{mg}$ of dried soil sample was digested using $50 \%(\mathrm{v} / \mathrm{v}) \mathrm{HNO}_{3}$, placed in a Teflon bottle, diluted to $108 \mathrm{ml}$, and transferred to $15 \mathrm{ml}$ vials for ICP-MS analysis. The basic procedure applied was BCR sequential extraction, due to its high reproducibility in systematic studies of trace metals in soil components. The code of the reference material for chemical measurements was Soil GBW-07,408.

\section{Statistical and spatial analyses}

Correlations between concentrations of $\mathrm{La}$ and $\mathrm{Ce}$ and magnetometric measures were investigated using Spearman's correlation coefficient. Spatial correlations of $\kappa$ values measured on the soil surface and concentrations of $\mathrm{La}$ and $\mathrm{Ce}$ were analyzed using variograms (Goovaerts 1997; Zawadzki and Fabijańczyk 2007; Zolfaghari et al. 2015). Experimental variograms were calculated according to the formula:

$$
\gamma(\mathbf{h})=\frac{1}{2 N} \sum_{i=1}^{N}\left[Z\left(\mathbf{x}_{i}\right)-Z\left(\mathbf{x}_{i}+\mathbf{h}\right)\right]^{2},
$$

where: $\mathbf{x}_{i}$ is a location, $\mathbf{h}$ is a lag vector, $Z\left(\mathbf{x}_{i}\right)$ is a $\kappa$ value measured at the location $\mathbf{x}_{i}$, and $N$ is the number of pairs spaced by $\mathbf{h}$ vector. Calculation of the experimental variograms was performed in the SGeMS software (Remy et al. 2009). Experimental variograms were modeled using spherical model using parameters such as a nugget effect, a range of correlation, and a sill. In addition, nugget-to-sill ratios were calculated.

\section{Results and discussion}

As it was analyzed (Table 2), the average concentrations of all $\mathrm{La}$ and $\mathrm{Ce}$ that were measured in all study areas were within the typical range for this part of Poland, 2.7-35 mg kg${ }^{-1}$ and $5.5-72 \mathrm{mg} \mathrm{kg}^{-1}$, respectively, for La and Ce (Ramos et al. 2016; Hu et al. 2006; Salminen et al. 2005). High concentrations of $\mathrm{La}$ and Ce (Table 2 and Fig. 2) were measured in soils of arable fields (area A).

The main reason for the high concentrations of $\mathrm{La}$ and $\mathrm{Ce}$ in soils in area A was pollution with dust coming from the heap of the plant producing and processing batteries. The increased concentrations of $\mathrm{La}$ and $\mathrm{Ce}$ in arable soils may have been also the result of a use of fertilizers that can contain significant amounts REE (Cao et al. 2001). Measured concentrations of $\mathrm{La}$ and $\mathrm{Ce}$ reached over $23 \mathrm{mg} \mathrm{kg}^{-1}$ and $50 \mathrm{mg} \mathrm{kg}^{-1}$, respectively, both in the topsoil and subsoil. As it was observed, the distributions of La and Ce (Fig. 2) concentrations in soil were only slightly skewed what can be attributed to the cultivation processes. Systematic mixing of the upper soil layer, combined with the ability to accumulate REE by cultivated plants, eliminated the occurrence of extreme concentrations of $\mathrm{La}$ and $\mathrm{Ce}$.

In the Jizera Mountains (areas D1 and D2), measured concentrations of $\mathrm{La}$ and $\mathrm{Ce}$ in soils reached over $30 \mathrm{mg} \mathrm{kg}^{-1}$ and $70 \mathrm{mg} \mathrm{kg}^{-1}$, respectively. Increased concentration of REE in soil could have resulted from significant amounts of REE which could come from a nearby power plant located in neighboring regions of Germany, Poland, and Czechia. REE contained in volatile dusts (Jarosinski 2016), which were deposited on the soil surface, were subsequently accumulated in very thin organic soil horizon, in the topsoil. However, earlier analyses (Kowalczyk 1989) showed also that high concentrations of $\mathrm{La}$ and $\mathrm{Ce}$ are present in the subsoil, and they could be even higher than those measured in the topsoil. As it was mentioned in the Introduction section, in this part of Poland, in the region of the Jizera Mountains, natural REE-rich minerals such as monazite, xenotile, apatite, and zirconium are very common. However, strong positive skewness of distributions of $\mathrm{La}$ and $\mathrm{Ce}$ which was observed for area D2 (Table 1), suggested rather the anthropogenic origin of $\mathrm{La}$ and $\mathrm{Ce}$, related to long-lasting deposition of industrial dusts. Contrary, in the area D1, 
Table 2 Descriptive statistics of concentrations of $\mathrm{La}, \mathrm{Ce}$ in topsoil (top) and subsoil (sub) that were measured using soil cores collected in areas A, B1, $\mathrm{B} 2, \mathrm{C} 1, \mathrm{C} 2, \mathrm{C} 3$, and D

\begin{tabular}{|c|c|c|c|c|c|c|c|c|c|c|}
\hline \multirow{3}{*}{$\begin{array}{l}\text { Area } \\
\text { A }\end{array}$} & \multicolumn{2}{|c|}{ Soil level } & \multirow{3}{*}{$\begin{array}{l}\text { Average } \\
{\left[\begin{array}{l}\mathrm{mg} / \mathrm{kg}] \\
18.7\end{array}\right.}\end{array}$} & \multirow{3}{*}{$\begin{array}{r}\text { Min } \\
15.1\end{array}$} & \multirow{3}{*}{$\begin{array}{l}\text { Max } \\
23.7\end{array}$} & \multirow{3}{*}{$\begin{array}{l}\mathrm{Q} 25 \% \\
16.7\end{array}$} & \multirow{3}{*}{$\begin{array}{l}\text { Q75\% } \\
21.4\end{array}$} & \multirow{3}{*}{$\begin{array}{l}\begin{array}{l}\text { Standard } \\
\text { deviation }\end{array} \\
2.7\end{array}$} & \multirow{3}{*}{$\begin{array}{l}\begin{array}{l}\text { Coefficient } \\
\text { of variation } \\
{[-]}\end{array} \\
14.2\end{array}$} & \multirow{3}{*}{$\begin{array}{c}\text { Skewness } \\
0.49\end{array}$} \\
\hline & & & & & & & & & & \\
\hline & $\mathrm{La}$ & top & & & & & & & & \\
\hline & & sub & 18.5 & 14.7 & 21.7 & 16.7 & 19.8 & 2.3 & 12.2 & -0.05 \\
\hline & $\mathrm{Ce}$ & top & 39.4 & 31.1 & 50.2 & 34.8 & 46.0 & 6.2 & 15.7 & 0.51 \\
\hline & & sub & 39.2 & 31.2 & 46.3 & 34.2 & 44.1 & 5.1 & 13.0 & -0.15 \\
\hline \multirow[t]{4}{*}{ B1 } & $\mathrm{La}$ & top & 15.5 & 7.2 & 24.7 & 10.4 & 20.6 & 6.4 & 41.6 & 0.25 \\
\hline & & sub & 10.3 & 6.8 & 13.1 & 7.6 & 12.8 & 2.4 & 23.6 & -0.27 \\
\hline & $\mathrm{Ce}$ & top & 31.9 & 14.1 & 54.9 & 20.6 & 40.2 & 14.5 & 45.6 & 0.54 \\
\hline & & sub & 20.8 & 13.6 & 26.5 & 14.8 & 26.1 & 5.2 & 25.0 & -0.30 \\
\hline \multirow[t]{4}{*}{ B2 } & $\mathrm{La}$ & top & 8.6 & 1.8 & 13.2 & 6.0 & 12.2 & 4.1 & 48.1 & -0.50 \\
\hline & & sub & 13.3 & 9.4 & 21.1 & 10.1 & 15.8 & 4.4 & 32.8 & 1.34 \\
\hline & $\mathrm{Ce}$ & top & 18.8 & 3.7 & 25.4 & 15.5 & 24.0 & 7.8 & 41.3 & -1.42 \\
\hline & & sub & 27.1 & 19.9 & 41.3 & 20.4 & 32.1 & 8.2 & 30.4 & 1.23 \\
\hline \multirow[t]{4}{*}{ B3 } & $\mathrm{La}$ & top & 7.9 & 3.7 & 12.7 & 6.7 & 9.5 & 2.5 & 31.1 & 0.05 \\
\hline & & sub & 8.2 & 3.7 & 12.8 & 6.6 & 9.8 & 2.5 & 30.5 & 0.25 \\
\hline & $\mathrm{Ce}$ & top & 16.2 & 7.5 & 27.1 & 13.9 & 19.5 & 5.2 & 32.3 & 0.30 \\
\hline & & sub & 16.8 & 7.4 & 27.4 & 12.8 & 20.2 & 5.5 & 32.6 & 0.38 \\
\hline \multirow[t]{4}{*}{$\mathrm{C}$} & $\mathrm{La}$ & top & 5.3 & 1.8 & 14.1 & 3.0 & 6.8 & 3.3 & 62.3 & 1.35 \\
\hline & & sub & 10.1 & 2.1 & 22.0 & 3.7 & 17.1 & 8.9 & 88.1 & 0.69 \\
\hline & $\mathrm{Ce}$ & top & 10.3 & 3.4 & 28.3 & 5.9 & 13.3 & 6.5 & 63.1 & 1.40 \\
\hline & & sub & 20.9 & 4.2 & 45.5 & 7.5 & 35.8 & 18.5 & 88.5 & 0.67 \\
\hline \multirow[t]{4}{*}{ D1 } & $\mathrm{La}$ & top & 19.3 & 5.8 & 27.7 & 16.6 & 21.8 & 5.2 & 27.2 & -0.78 \\
\hline & & sub & 20.9 & 13.2 & 28.9 & 17.5 & 23.4 & 4.0 & 19.3 & 0.18 \\
\hline & $\mathrm{Ce}$ & top & 39.6 & 11.1 & 57.4 & 33.0 & 45.6 & 11.4 & 28.7 & -0.72 \\
\hline & & sub & 43.8 & 24.8 & 61.8 & 36.5 & 50.3 & 8.9 & 20.4 & -0.08 \\
\hline \multirow[t]{4}{*}{ D2 } & $\mathrm{La}$ & top & 20.3 & 11.2 & 34.1 & 12.4 & 30.9 & 9.0 & 44.1 & 0.79 \\
\hline & & sub & 25.0 & 12.9 & 50.7 & 20.7 & 25.7 & 12.0 & 47.9 & 2.05 \\
\hline & $\mathrm{Ce}$ & top & 37.4 & 21.7 & 72.0 & 24.8 & 41.0 & 17.0 & 45.3 & 1.65 \\
\hline & & sub & 43.4 & 22.9 & 53.3 & 42.8 & 47.9 & 9.7 & 22.3 & -1.95 \\
\hline
\end{tabular}

distributions of $\mathrm{La}$ and $\mathrm{Ce}$ concentration in the topsoil were negatively skewed. This observation can be explained by the industrial history of this area. Because of the work carried out in the glassworks in the past, large volumes of wastes were deposited in the neighboring areas being the source of high soil pollution with various contaminants.

The lowest concentrations of $\mathrm{La}$ and $\mathrm{Ce}$ in soil were observed in forested areas of USIR (B1, B2, B3, and C), where the dominant type of pollution sources was associated with the metallurgical industry that did not emit significant amounts of REE. Average concentration of La did not exceed $10 \mathrm{mg} \mathrm{kg}^{-1}$ and $15 \mathrm{mg} \mathrm{kg}^{-1}$ in the topsoil and subsoil, respectively. Measured concentrations of $\mathrm{Ce}$ were about two times higher than concentrations of $\mathrm{La}$ (Table 2). In the large urban park (area D), measured concentrations of La and Ce were clearly higher in the subsoil than in the upper parts of the soil. It was observed, because the area $\mathrm{C}$ was mainly located on initial soils developed in reclaimed areas after former sand exploitation. Because of poorly developed soil levels of initial soils, particularly low thickness of the organic soil horizon, the degree of $\mathrm{La}$ and $\mathrm{Ce}$ accumulation in the topsoil was low.

All above-described observations suggested that increased concentrations of $\mathrm{La}$ and $\mathrm{Ce}$ in soils in areas A, D1, and D2 could be rather a result of anthropogenic pollution than natural soil properties. To confirm this conjecture, the field magnetometry was employed. The magnetometric measurements, both on the soil surface and in soil profile, were carefully planned and carried out on all studied areas.

In the areas $\mathrm{A}$ and $\mathrm{C}$, the average measured value of $\kappa$ exceed $100 \times 10^{-6} \mathrm{SI}$ (Fig. 2). Basing on the studies carried out so far (Zawadzki et al. 2009; Magiera et al. 2007; Strzyszcz and Magiera 1998), such values of $\kappa$ suggested strong soil contamination with anthropogenic, magnetic pollutants. The reason for observing such high values of $\kappa$ was the direct proximity of large emission sources. In the case 
of the area A, it was a waste heap, whereas, for the area C, it was a metallurgical plant.

In the Jizera Mountains (areas D1 and D2), the smallest average values of $\kappa$ were observed. However, distinctive differences were found between $\kappa$ values measured in area D1 and D2, respectively. In area D2, maximum measured $\kappa$ was equal to $32 \times 10^{-6} \mathrm{SI}$, while, in the area D1, maximum $\kappa$ reached over $200 \times 10^{-6}$ SI. Such observation finds the explanation in the industrial history of the area D1. Past activities of glasswork Carlsthal (Czihak 1891) and significant volumes of wasted that were deposited in the glade contributed to the observation of a significant number of extreme $\kappa$ values. Consequently, despite the rather low value of the average $\kappa$ in the area D1, the result of magnetometric measurements revealed significant soil pollution in this area. In the area D2, almost no extreme values of $\kappa$ were noted, and consequently, this area could be only classified as slightly polluted.

In areas B1, B2, and B3 located in USIR, measured values of $\kappa$ were ranging between $5 \times 10^{-6} \mathrm{SI}$ and $115 \times 10^{-6} \mathrm{SI}$, and were similar in all three areas. Based on the magnetometric measurements and previous results, soils of these areas could be classified as moderately contaminated.

The highest values of an area under a curve of $\kappa$ in collected soil profiles were observed in areas that were located in USIR, namely A, B1, B2, B3, and C (Table 3). In these areas, calculated average values of an area under a curve of $\kappa$ ranged from about $70 \times 10^{-6} \mathrm{~mm}$ to over $100 \times 10^{-6} \mathrm{~mm}$. However, on the arable field located near the waste heap (Fig. 1), extreme values reaching up to about $500 \times 10^{-6} \mathrm{~mm}$ were measured. The smallest calculated values of an area under a curve of $\kappa$ were observed in areas located in the Jizera Mountains D1, and D2. Nevertheless, these areas were located on mountain soils, whose individual soil levels had a small thickness.

The maximum measured value of $\kappa$ in a soil core and calculated $\chi$ were especially sensitive and reliable magnetometric indicators of potential soil pollution, because they refer to those parts of soil cores where the most of pollutants are accumulated. As it can be observed in Table 3, values $\chi$ of soil samples collected on the field A were the highest, reaching over $700 \times 10^{-6} \mathrm{~m}^{3} \mathrm{~kg}^{-1}$. In areas B1, B2, B3, C that were located in the USIR, values of $\chi$ were also high, with the average $\chi$ exceeding $100 \times 10^{-6} \mathrm{~m}^{3} \mathrm{~kg}^{-1}$. In the Jizera Mountains, values of $\chi$, but also of maximum measured value of $\kappa$ in collected soil cores, were about four times lower than those measured in the USIR.

Such observations may have resulted from a different, predominant type of anthropogenic pressure in USIR and the Jizera Mountains. Although the anthropogenic pressure in the Jizera Mountains also exists, it is mainly caused by the fall of volatile dusts coming from fossil fuel power plants. These types of pollutants are characterized by much weaker magnetic properties compared to pollutants emitted from the metallurgical industry, which was main source of soil pollution in areas A, B1, B2, B3, C, located in the USIR.

Collected soil cores were also used to measure distributions of $\kappa$ values in soil profiles, to verify whether, in the studied area, increased La and Ce contents in the soil resulted from pollution or natural soil properties. As previously studied by Magiera et al. (2006), several characteristic types of distributions of $\kappa$ values in soil profiles have been distinguished. In the case when the distinctive peak of the $\kappa$ value was located at the depth of a few centimeters in the soil profile, the soil was under strong anthropogenic pressure. The increase of $\kappa$ values caused by lithogenic factors was generally observed as a mild peak of $\kappa$ values in the lower parts of the soil profile, at depths exceeding $10 \mathrm{~cm}$.

The systematic analysis of collected soil cores showed that distributions of $\kappa$ in areas D2, B2, B3, and C, were characteristic for the presence of strong anthropogenic pollution (Fig. 3). It was observed that the magnetic particles were mostly accumulated at the depth of about $4 \mathrm{~cm}-8 \mathrm{~cm}$. Next, along with a depth increase, values of $\kappa$ were rapidly decreasing, and then starting from the depth of about $10 \mathrm{~cm}$, they were stabilizing.

Distributions of $\kappa$ in the soil profile that were characteristic for contaminated soils were also observed in area D1; however, the shapes of these distributions were quite different from those observed in areas D2, B2, B3, and C. As it can be observed in the Fig. 3, in the area D1, the peak characteristic for anthropogenic pollution was located at the depth of about $3 \mathrm{~cm}$, but the values of $\kappa$ were not substantially decreasing along with a depth in the soil profile, and additional wide peak of $\kappa$ values was observed at the depth from 12 to $16 \mathrm{~cm}$. This second peak was a result of the soil pollution caused by large volumes of wastes deposited in the area D1 in nineteenth century.

In agricultural areas, as expected, measurements of $\kappa$ in the soil profile were of little use due to the lack of characteristic soil levels, which was caused by regular cultivation. As it can be observed in Fig. 3, on both arable fields (areas $\mathrm{A}$ and B1), $\kappa$ values were rapidly increasing, reaching its maximum at the depth of about $5 \mathrm{~cm}$, and after that were almost constant in the rest of soil core.

After conducting chemical and magnetometric measurements, Spearman's correlation coefficients between the magnetometric measurements and the contents of La and $\mathrm{Ce}$ in the soil were calculated and carefully analyzed. It is important to stress that only the measurements of $\mathrm{La}$ and $\mathrm{Ce}$ content carried out in the topsoil layer were used in the correlation analysis. This was because the range of penetration of the MS2D sensor used for surface measurements of the soil was limited to $10 \mathrm{~cm}$ (Dearing 1994). It is also important to notice that, despite the Bartington MS2D penetrates to a depth of $10 \mathrm{~cm}$, the effective penetration depth is only 
Table 3 Descriptive statistics of magnetic parameters $\kappa, \chi$, an area under a curve of $\kappa$ (AREA) and maximum value (MAX) of $\kappa$ in collected soil cores that were measured in areas A, B1, $\mathrm{B} 2, \mathrm{C} 1, \mathrm{C} 2, \mathrm{C} 3$, and D

\begin{tabular}{|c|c|c|c|c|c|c|c|c|}
\hline Area & Average & Min & Max & Q25\% & Q75\% & Standard deviation & $\begin{array}{l}\text { Coefficient of } \\
\text { variation [\%] }\end{array}$ & Skewness [-] \\
\hline \multicolumn{9}{|c|}{$\left[10^{-5} \mathrm{SI}\right]$} \\
\hline \multicolumn{9}{|l|}{$\kappa$} \\
\hline A & 136 & 15.0 & 272 & 107 & 157 & 45 & 33 & 0.54 \\
\hline B1 & 38 & 15.0 & 70 & 29 & 46 & 10 & 28 & 0.23 \\
\hline B2 & 46 & 5.0 & 115 & 30 & 59 & 22 & 47 & 0.56 \\
\hline B3 & 51 & 10.0 & 100 & 38 & 64 & 18 & 36 & 0.18 \\
\hline $\mathrm{C}$ & 106 & 19.0 & 501 & 64 & 131 & 64 & 60 & 1.81 \\
\hline D1 & 14 & 1.0 & 205 & 5 & 11 & 23 & 169 & 4.99 \\
\hline $\mathrm{D} 2$ & 12 & 1.0 & 32 & 8 & 16 & 5 & 44 & 0.35 \\
\hline \multicolumn{9}{|c|}{$\left[\mathrm{mm} \times 10^{-5} \mathrm{SI}\right]$} \\
\hline \multicolumn{9}{|l|}{$\chi$} \\
\hline A & 214.3 & 39.7 & 763.7 & 123.0 & 247.5 & $24,502.7$ & 73 & 156.5 \\
\hline B1 & 179.5 & 41.5 & 372.4 & 100.1 & 251.7 & 9436.9 & 54 & 97.1 \\
\hline $\mathrm{B} 2$ & 139.5 & 60.3 & 325.4 & 85.0 & 110.5 & $11,351.3$ & 76 & 106.5 \\
\hline B3 & 112.8 & 33.4 & 259.4 & 81.5 & 151.9 & 3024.8 & 49 & 55.0 \\
\hline $\mathrm{C}$ & 145.7 & 42.9 & 330.5 & 94.4 & 207.1 & 5779.1 & 52 & 76.0 \\
\hline D1 & 48.6 & 9.2 & 222.3 & 14.1 & 36.1 & 3778.5 & 127 & 61.5 \\
\hline D2 & 24.7 & 7.5 & 32.8 & 23.0 & 32.2 & 66.7 & 33 & 8.2 \\
\hline \multicolumn{9}{|c|}{$\left[10^{-8} \mathrm{~m}^{3} / \mathrm{kg}\right]$} \\
\hline \multicolumn{9}{|c|}{ Area } \\
\hline $\mathrm{A}$ & 125.7 & 31.0 & 476.5 & 62.0 & 144.0 & 8602.7 & 74 & 92.8 \\
\hline B1 & 109.1 & 27.0 & 229.0 & 73.0 & 139.0 & 2491.6 & 46 & 49.9 \\
\hline B2 & 115.5 & 42.0 & 267.0 & 69.5 & 91.0 & 7564.5 & 75 & 87.0 \\
\hline B3 & 73.5 & 25.5 & 118.0 & 57.0 & 87.5 & 744.6 & 37 & 27.3 \\
\hline $\mathrm{C}$ & 109.0 & 25.5 & 202.0 & 78.0 & 155.0 & 2541.7 & 46 & 50.4 \\
\hline D1 & 20.9 & 5.0 & 80.0 & 7.0 & 26.0 & 392.6 & 95 & 19.8 \\
\hline D2 & 13.1 & 4.0 & 20.0 & 9.0 & 16.0 & 26.1 & 39 & 5.1 \\
\hline \multicolumn{9}{|c|}{$\left[10^{-5} \mathrm{SI}\right]$} \\
\hline \multicolumn{9}{|c|}{$\operatorname{Max}$} \\
\hline $\mathrm{A}$ & 162.0 & 8.0 & 295.0 & 107.0 & 237.0 & 6063.3 & 48 & 77.9 \\
\hline B1 & 45.4 & 33.5 & 64.0 & 40.4 & 50.2 & 71.7 & 19 & 8.5 \\
\hline B2 & 119.6 & 20.5 & 281.0 & 53.0 & 151.5 & 7595.1 & 73 & 87.2 \\
\hline B3 & 104.9 & 12.8 & 347.0 & 57.0 & 131.3 & 5587.2 & 71 & 74.7 \\
\hline $\mathrm{C}$ & 157.7 & 9.8 & 508.0 & 46.6 & 229.0 & $17,997.5$ & 85 & 134.2 \\
\hline D1 & 32.3 & 1.2 & 267.0 & 11.7 & 33.5 & 2103.5 & 142 & 45.9 \\
\hline D2 & 42.2 & 7.8 & 98.3 & 12.1 & 61.2 & 1023.8 & 76 & 32.0 \\
\hline
\end{tabular}

about $6 \mathrm{~cm}$, and the response of the soil volume is not linear (Lecoanet et al. 1999).

As it was presented in Table 3, concentrations of La and $\mathrm{Ce}$ in all analyzed areas were significantly mutually correlated, and values of Spearman's correlation coefficients were relatively high. Such results suggested the concentrations of $\mathrm{La}$ and $\mathrm{Ce}$ in the soil in the industrial areas located in the USIR and in the Jizera Mountains could have originated from the same source. However, it was rather difficult to distinguish whether it was of an anthropogenic or natural origin. In the same time, it turned out that the values of $\kappa$ measured on the soil surface were much weaker correlated with the concentrations of La and Ce. This was observed both in the areas located in the USIR and in the Jizera Mountains. However, it was also found that values of magnetometric indicators AREA and maximum measured value of $\kappa$ in collected soil cores calculated from the soil core measurements in the area A (Table 4) were quite well correlated with concentrations of $\mathrm{La}$ and $\mathrm{Ce}$.

These results reveal that, in the area contaminated by dust coming from the heap, the magnetometric indicators AREA and maximum measured value of $\kappa$ in collected soil cores might be particularly helpful for delineation of elevated concentrations of $\mathrm{La}$ and $\mathrm{Ce}$ in the soil around the heaps 


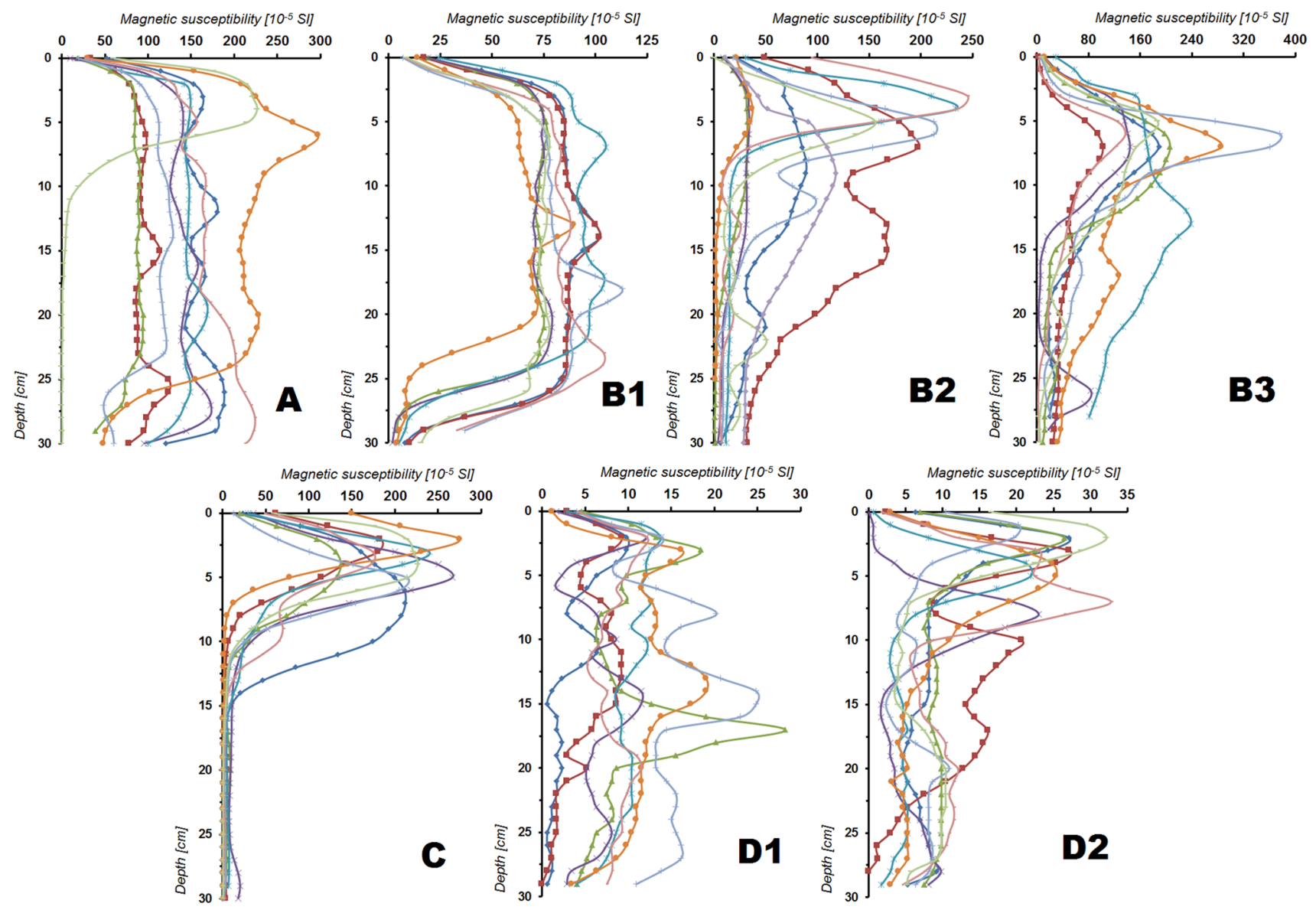

Fig. 3 Distributions of magnetic susceptibility in soil profiles that were collected in study areas A, B1, B2, C1, C2, C3, and D

Table 4 Values of Spearman's correlation coefficients between $\kappa, \chi$, an area under a curve of $\kappa$ (AREA), maximum value (MAX) of $\kappa$ in collected soil cores, and concentrations of $\mathrm{La}$ and $\mathrm{Ce}$ in topsoil; values marked in bold are statistically significant $(\alpha=0.05)$

\begin{tabular}{|c|c|c|c|c|c|c|}
\hline & $\mathrm{La}$ & $\mathrm{Ce}$ & $\kappa$ & $\chi$ & Area & $\operatorname{Max}$ \\
\hline \multicolumn{7}{|c|}{ Area A } \\
\hline $\mathrm{La}$ & - & 0.98 & 0.17 & 0.34 & 0.38 & 0.45 \\
\hline $\mathrm{Ce}$ & 0.98 & - & 0.12 & 0.36 & 0.40 & 0.44 \\
\hline \multicolumn{7}{|c|}{ Area B1 } \\
\hline $\mathrm{La}$ & - & 0.99 & 0.21 & -0.02 & -0.08 & -0.12 \\
\hline $\mathrm{Ce}$ & 0.99 & - & 0.23 & -0.04 & -0.08 & -0.15 \\
\hline \multicolumn{7}{|c|}{ Area B2 } \\
\hline $\mathrm{La}$ & - & 0.93 & 0.04 & -0.57 & -0.57 & -0.39 \\
\hline $\mathrm{Ce}$ & 0.93 & - & 0.08 & -0.53 & -0.53 & -0.31 \\
\hline \multicolumn{7}{|c|}{ Area B3 } \\
\hline $\mathrm{La}$ & - & 0.93 & 0.04 & -0.57 & -0.57 & -0.39 \\
\hline $\mathrm{Ce}$ & 0.93 & - & 0.08 & -0.53 & -0.53 & -0.31 \\
\hline \multicolumn{7}{|c|}{ Area C } \\
\hline $\mathrm{La}$ & - & 0.99 & -0.14 & 0.05 & -0.04 & 0.17 \\
\hline $\mathrm{Ce}$ & 0.99 & - & -0.15 & 0.03 & -0.05 & 0.15 \\
\hline \multicolumn{7}{|c|}{ Area D1 } \\
\hline $\mathrm{La}$ & - & 0.95 & -0.03 & 0.31 & 0.15 & -0.26 \\
\hline $\mathrm{Ce}$ & 0.95 & - & -0.13 & 0.29 & 0.14 & -0.24 \\
\hline \multicolumn{7}{|c|}{ Area D2 } \\
\hline $\mathrm{La}$ & - & 0.91 & -0.42 & -0.02 & -0.25 & 0.24 \\
\hline $\mathrm{Ce}$ & 0.91 & - & -0.65 & 0.14 & -0.06 & 0.23 \\
\hline
\end{tabular}


Table 5 Parameters of spherical models of variograms of $\mathrm{La}$ and $\mathrm{Ce}$ concentrations in soil, and $\kappa$ measured on the soil surface

\begin{tabular}{llll}
\hline Area Nugget effect & Sill & $\begin{array}{l}\text { Nugget- } \\
\text { to-sill } \\
\text { ratio }\end{array}$ & $\begin{array}{l}\text { Correlation range } \\
(\mathrm{m})\end{array}$ \\
& &
\end{tabular}

\begin{tabular}{|c|c|c|c|c|}
\hline \multicolumn{5}{|l|}{ A } \\
\hline $\mathrm{La}$ & Pure nugget & - & - & - \\
\hline $\mathrm{Ce}$ & Pure nugget & - & - & - \\
\hline$\kappa$ & $166 \times 10^{-10} \mathrm{SI}$ & $1680 \times 10^{-10} \mathrm{SI}$ & $9 \%$ & 135 \\
\hline \multicolumn{5}{|l|}{ B1 } \\
\hline $\mathrm{La}$ & $8(\mathrm{mg} / \mathrm{kg})^{2}$ & $20(\mathrm{mg} / \mathrm{kg})^{2}$ & $29 \%$ & 113 \\
\hline $\mathrm{Ce}$ & $30(\mathrm{mg} / \mathrm{kg})^{2}$ & $100(\mathrm{mg} / \mathrm{kg})^{2}$ & $23 \%$ & 150 \\
\hline$\kappa$ & $15 \times 10^{-10} \mathrm{SI}$ & $110 \times 10^{-10} \mathrm{SI}$ & $12 \%$ & 170 \\
\hline \multicolumn{5}{|l|}{ B2 } \\
\hline $\mathrm{La}$ & Pure nugget & - & - & - \\
\hline $\mathrm{Ce}$ & Pure nugget & - & - & - \\
\hline$\kappa$ & $75 \times 10^{-10} \mathrm{SI}$ & $490 \times 10^{-10} \mathrm{SI}$ & $13 \%$ & 70 \\
\hline \multicolumn{5}{|l|}{ B3 } \\
\hline $\mathrm{La}$ & Pure nugget & - & - & - \\
\hline $\mathrm{Ce}$ & Pure nugget & - & - & - \\
\hline$\kappa$ & $179 \times 10^{-10} \mathrm{SI}$ & $207 \times 10^{-10} \mathrm{SI}$ & $46 \%$ & 92 \\
\hline \multicolumn{5}{|l|}{$\mathrm{C}$} \\
\hline $\mathrm{La}$ & $6(\mathrm{mg} / \mathrm{kg})^{2}$ & $25(\mathrm{mg} / \mathrm{kg})^{2}$ & $19 \%$ & 1365 \\
\hline $\mathrm{Ce}$ & $28(\mathrm{mg} / \mathrm{kg})^{2}$ & $101(\mathrm{mg} / \mathrm{kg})^{2}$ & $22 \%$ & 1200 \\
\hline$\kappa$ & $387 \times 10^{-10} \mathrm{SI}$ & $3530 \times 10^{-10} \mathrm{SI}$ & $9 \%$ & 135 \\
\hline \multicolumn{5}{|l|}{ D1 } \\
\hline $\mathrm{La}$ & $9(\mathrm{mg} / \mathrm{kg})^{2}$ & $13(\mathrm{mg} / \mathrm{kg})^{2}$ & $42 \%$ & 165 \\
\hline $\mathrm{Ce}$ & $50(\mathrm{mg} / \mathrm{kg})^{2}$ & $115(\mathrm{mg} / \mathrm{kg})^{2}$ & $30 \%$ & 180 \\
\hline$\kappa$ & $32 \times 10^{-10} \mathrm{SI}$ & $690 \times 10^{-10} \mathrm{SI}$ & $4 \%$ & 150 \\
\hline \multicolumn{5}{|l|}{ D2 } \\
\hline $\mathrm{La}$ & Pure nugget & - & - & - \\
\hline $\mathrm{Ce}$ & Pure nugget & - & - & - \\
\hline$\kappa$ & $9 \times 10^{-10} \mathrm{SI}$ & $22 \times 10^{-10} \mathrm{SI}$ & $29 \%$ & 212 \\
\hline
\end{tabular}

reducing in this way the need to perform numerous geochemical measurements. In areas close to metallurgical or coal-fired power plants, less significant correlations between magnetometric indicators and concentrations of $\mathrm{La}$ and $\mathrm{Ce}$ in the soil were observed. This suggest that soil pollution with $\mathrm{La}$ and $\mathrm{Ce}$ coming from the heaps of the plant producing and processing batteries, or other electronic appliances may be predominant around the waste heaps.

Table 5 summarizes the variograms parameters calculated from geochemical and magnetometric measurements in the topsoil of studied areas. The nugget effect represents measurement error and spatial variation at distances shorter than the average distance between sample points, and thus, it is desired to obtain low values of a nugget effect. Second important parameter was a sill that represents the values of semivariogram at a distance where measured values are no more spatially correlated. This distance is called range of correlation. The parameter related to a sill and nugget-to-sill ratio is a nugget-to-sill ratio. As previously described by Cambardella et al. (1994) if nugget-to-sill ratio is below 0.25 , it can be assumed that the studied variable is strongly spatially correlated. Higher values, between 0.25 and 0.75 , suggest moderate spatial correlations, and if the ratio is greater than 0.75 , the variable is weakly spatially correlated.

As it can be seen in the table, spatial correlations of the concentrations of $\mathrm{La}$ and $\mathrm{Ce}$ in soils were, in some places, insignificant or difficult to analyze probably due to sparsity of geochemical measurements together with some complex field factors influencing these concentrations. For instance, in the arable field A where the experimental variograms from this area showed the pure nugget effect, it was not possible to find any correlation range. This may result from intensive cyclical agricultural activities such as ploughing or harrowing, which homogenize the topsoil and, in consequence, remove all spatial correlations related to the natural or anthropogenic mechanisms of soil pollution. However, it is worth noticing that it was possible to determine variograms parameters in all studied areas from much denser magnetometric measurements, which suggests their potential usefulness for spatial integration with geochemical measurements of the concentrations of $\mathrm{La}$ and $\mathrm{Ce}$.

\section{Conclusions}

Soil magnetometry was used to determine if the concentrations of $\mathrm{La}$ and $\mathrm{Ce}$ in soil could be a result of anthropogenic pollution or natural soil properties. Results of analyzes revealed that the highest concentrations of $\mathrm{La}$ and $\mathrm{Ce}$ were observed in the vicinity of a heap of battery post-processing wastes, and in the region of the Jizera Mountains, natural REE-rich minerals are very common. It was also found that the lowest concentrations of $\mathrm{La}$ and $\mathrm{Ce}$ in soil were observed in forested areas of where the dominant type of pollution sources was associated with the metallurgical industry.

It also turned out that magnetometric measurements made in soil profiles might be useful to differentiate between the natural and anthropogenic origin of REE concentration in soil. Distributions of magnetic susceptibility in soil profiles collected in areas with predominant industrial influence showed visible peak in topsoil, what confirmed anthropogenic origin of $\mathrm{La}$ and $\mathrm{Ce}$ in soil. In areas where large volumes of wastes were deposited in past, industrial activity, vertical distributions of soil magnetic susceptibility showed also secondary, strong peak in subsoil. Thus, the results reveal that magnetometric measurements in soil profile might be useful as supplementary method for analyzing of concentrations of rare-earth elements. 
Contrary, magnetometric measurements performed on the soil surface were poorly correlated with a concentration of $\mathrm{La}$ and $\mathrm{Ce}$ in soil, because they have weaker magnetic properties than typical fly ashes emitted by industry. It is also important to notice that supplementary magnetometric measurements, especially those made on the soil surface, had some drawbacks. This means that if similar magnetically enhanced layer, presumably containing also REE, is at one site shallower and at the other site deeper, surface measurements of magnetic susceptibility can yield significantly different values related to the same amount of REE.

Acknowledgements The research leading to these results was funding partially by the Polish-Norwegian Research Programme operated by the National Centre for Research and Development under the Norwegian, Financial Mechanism 2009-2014 in the frame of Project IMPACT - Contract No Pol-Nor/199338/45/2013, and partially by the statutory activities of Faculty of Building Services, Hydro and Environmental Engineering of Warsaw University of Technology.

Open Access This article is distributed under the terms of the Creative Commons Attribution 4.0 International License (http://creativeco mmons.org/licenses/by/4.0/), which permits unrestricted use, distribution, and reproduction in any medium, provided you give appropriate credit to the original author(s) and the source, provide a link to the Creative Commons license, and indicate if changes were made.

\section{References}

Ayoubi S, Amiri S, Tajik S (2014) Lithogenic and anthropogenic impacts on soil surface magnetic susceptibility in an arid region of central Iran. Arch Agron Soil Sci 60:1467-1483

Ayoubi S, Jabbari M, Khademi H (2018a) Multiple linear modeling between soil properties, magnetic susceptibility and heavy metals in various landuses. Model Earth Syst Environ 4:579-589

Ayoubi S, Soltani S, Khademi H (2018b) Particle size distribution of heavy metals and magnetic susceptibility in an industrial site. Bull Environ Con Toxicol 100:708-714

Beckwith R, Butler J (1993) Aspects of the chemistry of soil organic matter. In: Division of soils, CSIRO. Soils: an Australian viewpoint, chap 35, pp 565-581

Blaha U, Appel E, Stanjek H (2008) Determination of anthropogenic boundary depth in industrially polluted soil and semi-quantification of heavy metal loads using magnetic susceptibility. Environ Pollut 156:278-289

Cambardella CA, Moorman TB, Novak JM, Parkin TB, Karlen DK, Turco RF, Konopka AE (1994) Field-scale variability of soil properties in central Iowa soils. Soil Sci Soc Am J 58:1501-1511

Cao X et al (2001) Effects of redox potential and $\mathrm{pH}$ value on the release of rare earth elements from soil. Chemosphere 44:655-661

Cao L, Appel E, Hu S, Yin G, Lin H, Rösler W (2015) Magnetic response to air pollution recorded by soil and dust-loaded leaves in a changing industrial environment. Atmos Environ 119:304-313

Czihak E (1891) Schlesische Gläser, Breslau, ISBN-10: 3870572086

Dankoub Z, Ayoubi S, Khademi H, Sheng-Gao L (2011) Spatial distribution of magnetic properties and selected heavy metals as affected by land use in calcareous soils of the Isfahan Region, Central Iran. Pedosphere 22:33-47
Dearing JA (1994) Environmental magnetic susceptibility: using the Bartington MS2 system. Chi Publishing, Kenilworth

Fabijańczyk P, Zawadzki J, Magiera T (2017) Magnetometric assessment of soil contamination in problematic area using empirical Bayesian and indicator kriging: a case study in Upper Silesia, Poland. Geoderma 308:69-77

Fürst Ch, Lorz C, Makeschin F (2009) Testing a soil magnetometry technique in a highly polluted industrial region in North-Eastern Germany. Water Air Soil Poll 202(1-4):33-43

Goovaerts P (1997) Geostatistics for natural resources evaluation. Oxford University Press, New York

Hu Z, Haneklaus S, Sparovek G, Schnug E (2006) Rare earth elements in soil. Commun Soil Sci Plant Anal 37:1381-1420

Jarosiński A (2016) Możliwości pozyskiwania metali ziem rzadkich w Polsce. Zeszyty Naukowe, Instytutu Gospodarki Surowcami Mineralnymi i Energią. Polskiej Akademii Nauk 92:75-88 (in polish)

Karimi R, Ayoubi S, Jalalian A, Sheikh-Hosseini AR, Afyuni M (2011) Relationships between magnetic susceptibility and heavy metals in urban topsails in the arid region of Isfahan, central Iran. J Appl Geophys 74:1-7

Kowalczyk J, Mazanek C. Metale ziem rzadkich i ich związki. Warszawa, 1989, WNT

Lecoanet H, Leveque F, Segura S (1999) Magnetic susceptibility in environmental applications: comparison of field probes. Phys Earth Planet Inter 115:191-204

Łukasik A, Szuszkiewicz M, Magiera T (2015) Impact of artifacts on topsoil magnetic susceptibility enhancement in urban parks of the Upper Silesian conurbation datasets. J Soils Sediment 15:1836-1846

Magiera T, Szuszkiewicz P, Zawadzki J, Fabijańczyk P, Efficiency of soil magnetometry for assessment of chemical degradation caused by dust deposition. XXVI General Assembly of The International Union of Geodesy and Geophysics "Earth and Environmental Sciences for Future Generation”, 28.06.2015, Prague, Czechia

Magiera T, Zawadzki J (2007) Using of high-resolution topsoil magnetic screening for assessment of dust deposition: comparison of forest and arable soil datasets. Environ Monit Assess 125:19-28

Magiera T, Strzyszcz Z, Kapička A, Petrovsky E (2006) Discrimination of lithogenic and anthropogenic influences on topsoil magnetic susceptibility in Central Europe. Geoderma 130:299-311

Magiera T, Strzyszcz Z, Rachwał M (2007) Mapping particulate pollution loads using soil magnetometry in Urban forests in the Upper Silesia Industrial Region, Poland. Forest Ecol Manag 248:36-42

Magiera T, Strzyszcz Z, Jabłońska M, Rachwał M (2011) Morphological and mineralogical forms of technogenic magnetic particles in industrial dusts. Atmos Environ 45(25):4281-4290

Naimi S, Ayoubi S (2013) Vertical and horizontal distribution of magnetic susceptibility and metal contents in an industrial district of central Iran. J Appl Geophys 96:55-66

Petrovský E, Kapička A, Jordanova N, Knab M, Hoffmann V (2000) Low-field magnetic susceptibility: a proxy method of estimating increased pollution of different environmental systems. Environ Geol 39:312-318

Ramos SJ, Dinali GS, Oliveira C et al (2016) Rare earth elements in the soil environment. Curr Pollution Rep 2:28-50

Ran Y, Liu Z (1993) Adsorption and desorption of rare earth elements on soils and synthetic oxides. Acta Sci Circum 13(3):287-293

Remy N, Boucher A, Wu J (2009) Applied geostatistics with SGeMS: a user's guide. Cambridge University Press, Cambridge

Salminen R, Batista MJ, Bidovec M, Demetriades A, De Vivo B, De Vos W, Duris M, Gilucis A, Gregorauskiene V, Halamic J, Heitzmann P, Lima A, Jordan G, Klaver G, Klein P, Lis J, Locutura J, Marsina K, Mazrek UA, O'Connor PJ, Olsson SÅ, Ottesen RT, Petersell V, Plant JA, Reeder S, Salpeteur I, Sandström H, Siewers U, Steenfelt A, Tarvainen T (2005) Geochemical atlas of Europe. 
Part 1 - Background information, methodology and maps. ISBN: 951-690-921-3

Seredin VV, Dai S (2012) Coal deposits as potential alternative sources for lanthanides and yttrium. Int J Coal Geol 94:67-93

Spiteri C, Kalinski V, Rosler W, Hoffman V, Appel E (2005) Magnetic screening of pollution hotspots in the Lausitz Area, Eastern Germany: correlation analysis between magnetic proxies and heavy metal concentration in soil. Environ Geol 49:1-9

Strzyszcz Z, Magiera T (1998) Magnetic susceptibility of forest soils in Polish-German border area. Geol Carpath 49(4):241-242

Zawadzki J, Fabijańczyk P (2007) Use of variograms for field magnetometry analysis in Upper Silesia Industrial Region. Stud Geophys Geod 51:535-550
Zawadzki J, Fabijańczyk P, Magiera T (2009) Geostatistical evaluation of magnetic indicators of forest soil contamination with heavy metals. Stud Geophys Geod 53(1):133-149

Zolfaghari Z, Ayoubi S, Mosaddeghi MR (2015) Spatial variability of some soil shrinkage indices in hilly calcareous region of western Iran. Soil Tillage Res 150:180-191

Publisher's Note Springer Nature remains neutral with regard to jurisdictional claims in published maps and institutional affiliations. 